Article

\title{
Environmental Assessment of Recycling (EAoR) for Safe Recycling of Steelmaking Slag in the Republic of Korea: Applications, Leaching Test, and Toxicity
}

\author{
Min-Yong Lee $\mathbb{1}$, Jang-Hyun Kang, Dong-Gun Hwang, Young-Sam Yoon, Myung-Soo Yoo and Tae-Wan Jeon * \\ Department of Environmental Resources Research, National Institute of Environmental Research, Seogu, \\ Incheon 22689, Korea; danlee0702@gmail.com (M.-Y.L.); kang003553@korea.kr (J.-H.K.); \\ lunalian@korea.kr (D.-G.H.); ysyoon3sf@korea.kr (Y.-S.Y.); winmsy@korea.kr (M.-S.Y.) \\ * Correspondence: jeonsa@korea.kr
}

check for updates

Citation: Lee, M.-Y.; Kang, J.-H.; Hwang, D.-G.; Yoon, Y.-S.; Yoo, M.-S.; Jeon, T.-W. Environmental Assessment of Recycling (EAoR) for Safe Recycling of Steelmaking Slag in the Republic of Korea: Applications, Leaching Test, and Toxicity. Sustainability 2021, 13, 8805. https:// doi.org/10.3390/su13168805

Academic Editor: Jose Navarro Pedreño

Received: 6 July 2021

Accepted: 4 August 2021

Published: 6 August 2021

Publisher's Note: MDPI stays neutral with regard to jurisdictional claims in published maps and institutional affiliations.

Copyright: (c) 2021 by the authors. Licensee MDPI, Basel, Switzerland. This article is an open access article distributed under the terms and conditions of the Creative Commons Attribution (CC BY) license (https:// creativecommons.org/licenses/by/ $4.0 /)$.
Keywords: steelmaking slag; recycling; application; waste management; environmental assessment of recycling

\section{Introduction}

The production of global steel has increased from 2 million metric tons (Mt) in 1950 to 18.69 Mt in 2019 according to the World Steel Association [1] (Figure 1). China produces the largest quantity (53\%), followed by the European Union $(8.5 \%)$, India $(6.0 \%)$, and Japan (5.3\%) (Figure 2) [2]. In addition to consuming large amounts of raw materials and energy, the steel industry also generates large quantities of various by-products and waste types, through complex production processes such as raw material treatment, ironmaking, steelmaking, and rolling. Of these by-products, 27.68 Mt of slag were generated in 2019, which comprised $16.56 \mathrm{Mt}$ of blast furnace slag and $11.12 \mathrm{Mt}$ of steelmaking slag [3]. 


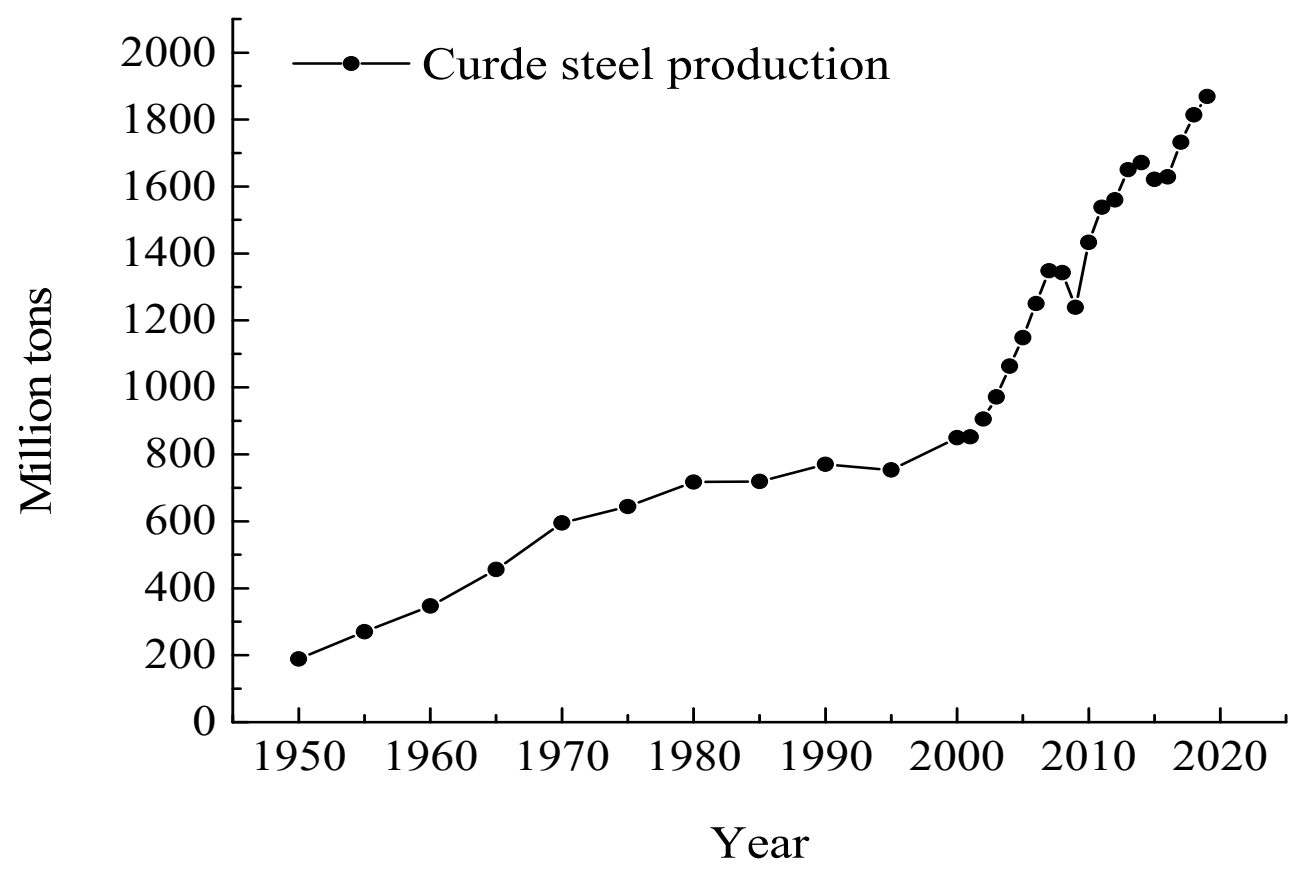

Figure 1. Global crude steel production from 1950 to 2019.

Crude steel productioin

World total: 1869 million tons

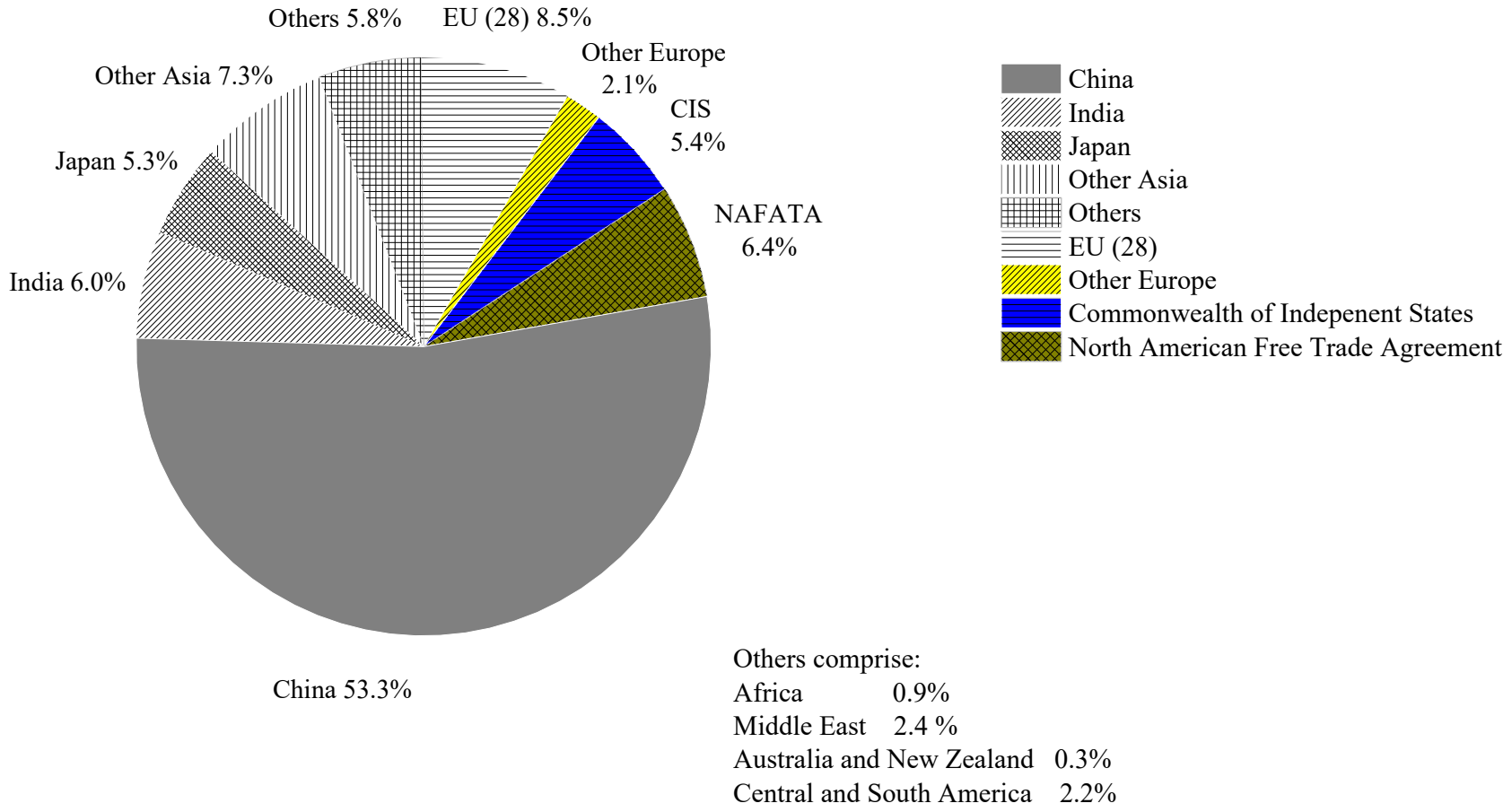

Figure 2. Worldwide distribution of steel production (2019).

In the Republic of Korea (ROK), blast furnace slag, converter furnace slag, and electric arc furnace slag are recycled for various applications; however, as there is limited demand for cement raw materials, concrete admixtures, and silicate fertilizer raw materials with high proportions of added slag, there is a need to develop the applications of recycled slag. 
Korean Standard (KS) regulations and guidelines are being implemented in relation to these issues, and studies are being conducted to increase utilization in areas beyond those where slag has traditionally been recycled. Such studies typically focus on using slag as an aggregate, as well as the use of not only blast furnace slag but also converter furnace and electric arc furnace slag. Aggregate demand in the ROK increased steadily from $201,424,000 \mathrm{~m}^{3}$ in 2014 to $231,770,000 \mathrm{~m}^{3}$ in 2018 , and is forecast to continue to increase due to future housing construction [4]. In these social conditions, the value and demand for steel slag as an aggregate is also expected to be infinite. Hence, various studies, mainly conducted by research institutes and universities, have examined how to supply aggregate to meet this demand.

Steel slag has been utilized for a long time. Europe began using steel slag for phosphate fertilizers as early as 1880 [5]. Owing to its chemical composition, comprising calcium oxide $(\mathrm{CaO}), \mathrm{Fe}$, iron oxide $(\mathrm{FeO})$, silicon dioxide $\left(\mathrm{SiO}_{2}\right)$, magnesium oxide $(\mathrm{MgO})$, and manganese oxide ( $\mathrm{MnO}$ ), steel slag can be used in steel mills (in both sintering and converter processes) [6,7] and for wastewater treatment due to its porous structure and alkalinity [8,9]. Sarfo et al. [10] investigated a carbothermal reduction method capable of recycling valuable metals from steelmaking slag and using residual slag in the glass and ceramic industries. Ferreira et al. [11] and Pasetto et al. [12] confirmed that steel slag can be effectively used as aggregate for road and hydropower construction due to its advantageous physical and mechanical properties, including hardness, wear resistance, adhesion, roughness, and toughness. Previous studies have reported that since steel slag contains $\mathrm{CaO}$ and $\mathrm{MgO}$, it can be reused to capture and store carbon dioxide $\left(\mathrm{CO}_{2}\right)[13,14]$. Studies have reported that the components of steel slag which are beneficial for promoting plant growth, such as $\mathrm{Si}, \mathrm{Ca}, \mathrm{Mg}, \mathrm{P}$, and Fe, can be reused for fertilizer and improving soil $[15,16]$.

Drissen et al. [17] reported that the greatest issue when internally reusing slag in steel mills is the enrichment of $\mathrm{P}$ and $\mathrm{S}$. The amount of free $\mathrm{CaO}$ and $\mathrm{MgO}$ is an important factor to consider when using steel slag in construction, as it affects volume stability. Nakase et al. [18] reported that the total Fe content and the leaching potential of heavy elements such as As, Cr, and V are key factors influencing the use of steel slag in cement production. In particular, Riley et al. [19] monitored the soil and rivers around steel mills and nearby stockpiles for over 36 years and reported that toxic slag-derived $\mathrm{V}$ had leaked into the groundwater and nearby rivers, thereby causing environmental damage. To the best of our knowledge, no study has been conducted on the hazardous assessment of steelmaking slag for diverse recycling. The estimation for various recycling and application of steelmaking slag such as content, leaching test, and toxicity evaluation, were performed. To understand the leaching characteristics for various environmental conditions, the characteristics and toxicity according to the use of distilled water and seawater were identified.

Regarding waste recycling management policy in the ROK, the Environmental Assessment of Recycling (EAoR) system for the safe recycling of waste has been reflected in the Wastes Control Act since July 2016. It includes a method for managing 11 types of hazardous substances, distinguishing between existing specified waste and general waste, and designating recyclable types to identify the impacts of waste recycling on humans and the environment. Moreover, evaluation items and methods have been improved and expanded for new recycling types, or recycling types for which no recycling standard had been designated. The EAoR system is divided into matrix contact types and non-matrix contact types. The former corresponds to waste recycled as filling and cover materials which can affect soil, groundwater, and the atmosphere, while the latter corresponds to recycled products that do not directly or indirectly affect the soil or water environment.

Since the introduction of the EAoR system, environmental pollution and disputes related to matrix contact recycling have increased; one possible cause is the application of unified standards without the pre-inspection and confirmation of waste types. Environmentally certified products (EL: Eco-Label, GR: Good Recycled, KS: Korean Standards) such as filling material, cover material, and aggregates, which incorporate waste as specified in the Environmental Technology and Industry Support Act, can be used as recycled 
products. However, some certified products do not satisfy the certification conditions that ensure environmental stability, and because matrix contact recycling sites that are less than $30,000 \mathrm{~m}^{2}$ in area or produce 120,000 tons of material are excluded from the Wastes Control Act, there is no way to check for potential environmental pollution after recycling.

According to Article 25 of the Act on the Promotion of Saving and Recycling of Resources and the Guidelines for Recycling Steel Slag and Coal Ash Discharging Business in the provisions of Article 35 under the same act (Ministry of Environment Notice No. 2009-285, Ministry of Knowledge Economy Notice No. 2009-326, 31 December 2009), the efficient use of resources relies on recycling of by-products generated in the production process. Relevant standards, design and construction guidelines, and target rates for recycling steel slag and coal ash (in relation to Articles 9 and 11) are said to enable recycling of these materials for various applications [20]. Such details include slag aging methods, categorized according to the application of recycled slag, and Korean industrial standards categorized by usage [20]. Accordingly, approximately $100 \%$ of steel slag is currently recycled as a recycled raw material, thus playing a major role in conserving resources and preserving the environment. Owing to the recent completion and operation of additional steel mills in the Republic of Korea, steel slag generation is forecasted to increase by more than $6 \mathrm{Mt}$ by 2025. Therefore, there is an urgent need to expand recycling applications and methods in line with this rapid increase in steel slag generation.

This study investigates the factors contributing to steel slag treatment, recycling, and management in the ROK. First, a general overview of steel slag is provided, and the chemical composition and utilization of steel slag in several countries are described. A historical overview of steel slag management and usage in the ROK is provided, and the laws, regulations, policies, and standards related to steel slag are explained. This study describes challenges that the ROK faces in terms of steel slag recycling. Finally, to promote the rational recycling of resources, specifically, by-products discharged by industrial processes, this study proposes a plan to improve the designated by-product (steel slag) system and promote recycling.

\section{Materials and Methods}

\subsection{Materials and Samples}

Deionized (DI) water was used from a Super-Genie E water purification stations (Rephile Bioscience Ltd., Philadelphia, Pennsylvania, USA). The $\mathrm{pH}$ was measured using a pH meter (Orion star A215, Thermo Fisher SCIENTIFIC, Waltham, MA, USA). The chemical composition of steel making slag was identified using X-ray fluorescence spectrometry (Panalystical Epsilon 3). The measurement of effective grain size was conducted using particle size analyzer (Laser scattering particle size distribution analyzer-LA960, HORIBA, Japan). The analysis of chemical composition was conducted using X-ray fluorescence (XRF) (Epsilon 4, Malvern Panalystical Ld, United Kingdom). The sample of steel making slag was collected from 16 steel companies in ROK. The sample was transported to the laboratory and stored at $4{ }^{\circ} \mathrm{C}$.

\subsection{Experimental Procedures}

\subsubsection{Leaching Test}

For the analysis of leaching characteristics, the method of leaching test in Waste Process Test Criteria (ES 06150.C) was used in this study. According to ES 06150.C, an eluate was prepared by shaking for $6 \mathrm{~h}$ at a high liquid ratio of 1:10 according to the dissolution test method, and then acid treated according to the conditions of the sample. The pretreated eluate was assessed for heavy metals using ICP-OES.

\subsubsection{Toxicity Test Using Aliivibrio fischeri}

The luminescent bacteria toxicity test was applied according to the acute toxicity test method using luminescent bacteria of the "Water Pollution Process Test Standards (ES 04706.1)" in the ROK, to evaluate the luminescence inhibition by exposing freeze-dried 
products or luminescent bacteria in culture (Aliivibrio fischeri) to control. After the sample was exposed for $30 \mathrm{~min}$, the luminescent was calculated using Equation (1). The sample was analyzed in quadruplicate.

$$
f_{k t}=I_{k t} / I_{0}(t=30 \mathrm{~min})
$$

where $f_{k t}$ is a correction factor for 30 min exposure; $I_{k t}$ is a luminous intensity in the control sample after $30 \mathrm{~min}$ exposure (Relative luminous unit); $I_{0}$ is a luminous intensity of the control test suspension immediately before the addition of the diluent (relative luminous unit).

The results were reported as the luminescent inhibition value, $1-\mathrm{L}_{t} / \mathrm{L}_{\mathrm{c}}$, where $\mathrm{L}_{\mathrm{t}}$ is the luminescent intensity of the sample and $\mathrm{L}_{\mathrm{c}}$ is the luminescent intensity of Aliivibrio fischeri with $3 \%$ sodium chloride.

The pretreatment was conducted following this procedure. The salinity of the sample was adjusted into $20 \mathrm{psu}$. The statistical analysis of the luminescent bacteria toxicity was conducted using the ToxCalc 5.0 program (Tidepool Scientific Software, McKinleyville, CA, USA).

\section{Results and Discussion}

\subsection{Historic Trends in the Republic of Korea}

Figure 3a shows the production of steel slag in the ROK over the last 10 years, classified into blast furnace slag and steelmaking slag. The domestic steel industry demonstrated stable growth in the 2010s; however, from the late 2010s, it entered an overall stagnation phase amid the sluggish global steel industry (Figure 3b). After the 2008 financial crisis, the strong growth of the Chinese economy fueled steel demand, which has shown steady growth since the early 2010s. From the late 2010s, both demand and production entered a stagnation phase because of the slowing growth of the Chinese economy, and the growth trend in the ROK has therefore slowed.

The steel industry is facing mounting difficulties, such as reduced domestic demand and exports due to the recent COVID-19 pandemic, lower sales, and profitability due to sluggish upstream industries, and a blow to exports caused by the spread of global protectionism. In the first half of 2020, domestic demand and exports of steel products decreased by $8.7 \%$ and $7.6 \%$ year-on-year, respectively. In the first half of 2020, domestic automobile production decreased by $19.8 \%$ and orders from shipbuilders decreased by $68.6 \%$ year-on-year. Consequently, the sales and operating performance of major steelmakers has decreased. Export difficulties are becoming more severe due to growing protectionism in major countries such as the United States.

Inorganic waste in the ROK is classified into 13 types and separately classified into 10 recycling types (R-1 to R-10), listed in Table 1 . Figure 4 shows the production of the 13 types of inorganic waste and the amount of R-7 recycled in the ROK in 2019. A total of $59.93 \mathrm{Mt}$ of the 13 types of inorganic waste were generated, of which slag $(23.03 \mathrm{Mt})$, inorganic sludge $(12.17 \mathrm{Mt})$, and combustion residue $(11.13 \mathrm{Mt})$ comprised $77 \%$. Figure 5 shows the amount of slag recycled by R-type. R-3, which can be made into a recoverable state or used for recycling, comprises $70.1 \%$ (1583.5 Mt); R-7, which is recycled as filling and cover material, road base material, banking, etc., in soil and public waters, accounted for $22.7 \%$ (513.7 Mt); while $\mathrm{R}-4$, which is directly recovered, comprised $6.4 \%$ of the total recycled slag (143.9 Mt). 

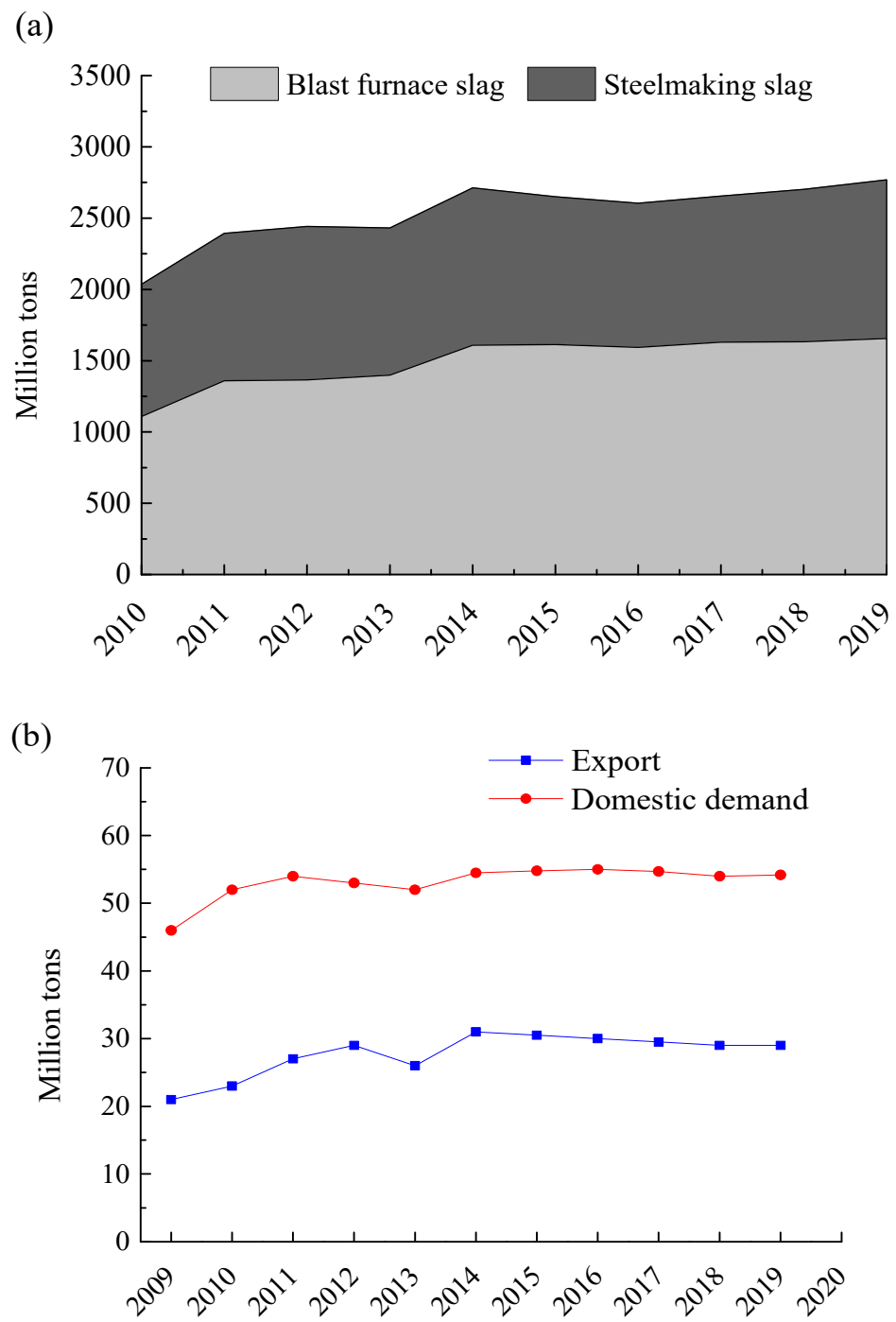

Figure 3. The production trend of (a) steel slag and (b) the trend of domestic demand and export in the Republic of Korea.

Table 1. Recycling types for inorganic waste in the Republic of Korea.

\begin{tabular}{cc}
\hline Type & Regulation and Standard \\
\hline R-1 & Original form or simply repair and reuse \\
\hline R-2 & Simply repair or wash and reuse \\
\hline R-3 & Can be made into a recoverable state or used for recycling \\
\hline R-4 & Directly recoverable \\
\hline R-5 & Recycling for agriculture or soil improvement \\
\hline R-6 & Recycling of organic materials to improve soil quality \\
\hline R-7 & Recycling as embankment materials, cover material, road layer material, \\
& Directly recovered as energy, or processed to be recoverable \\
\hline R-8 & Can be recovered as energy \\
\hline R-9 & A type of intermediate processed waste for product manufacturing \\
\hline R-10 &
\end{tabular}




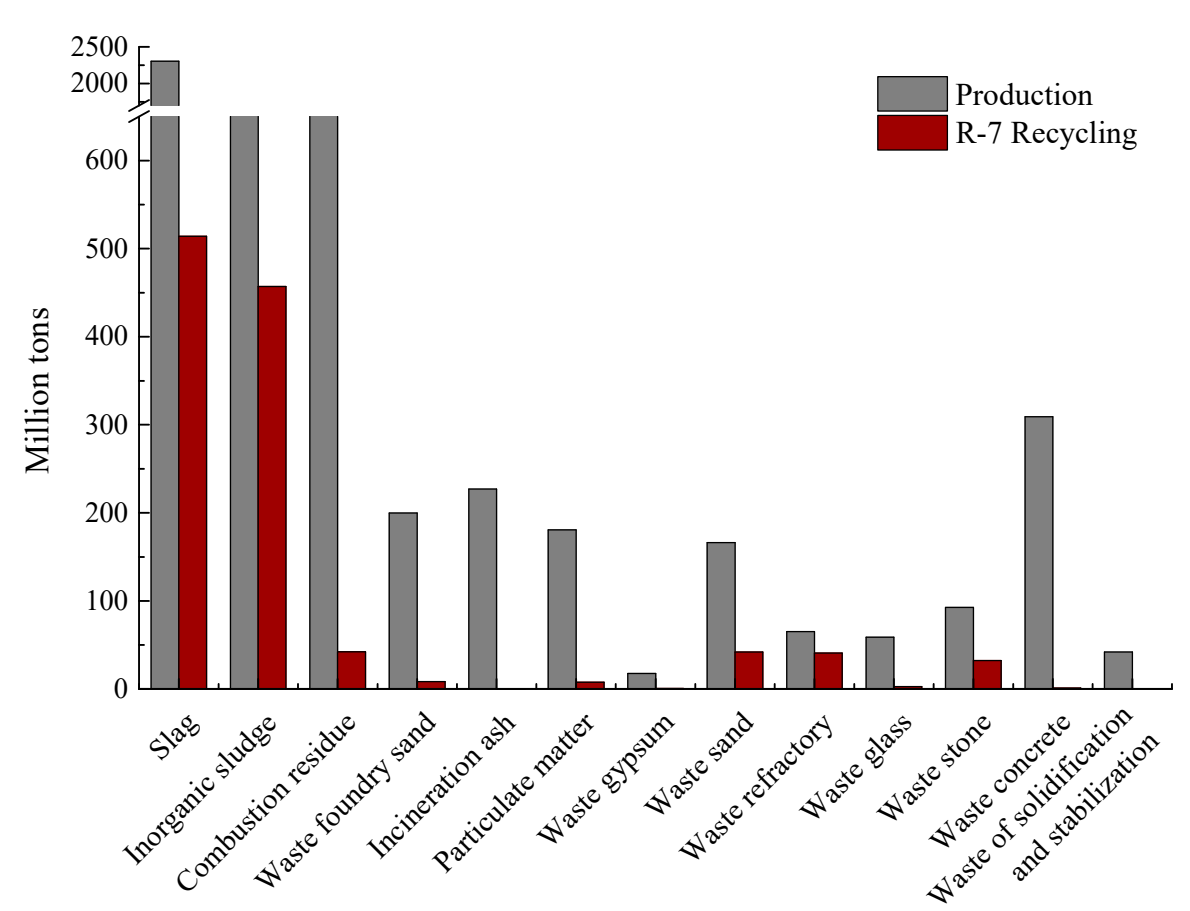

Figure 4. The production and recycling of inorganic waste in the Republic of Korea (2019).

\section{$\mathrm{R}-7$}

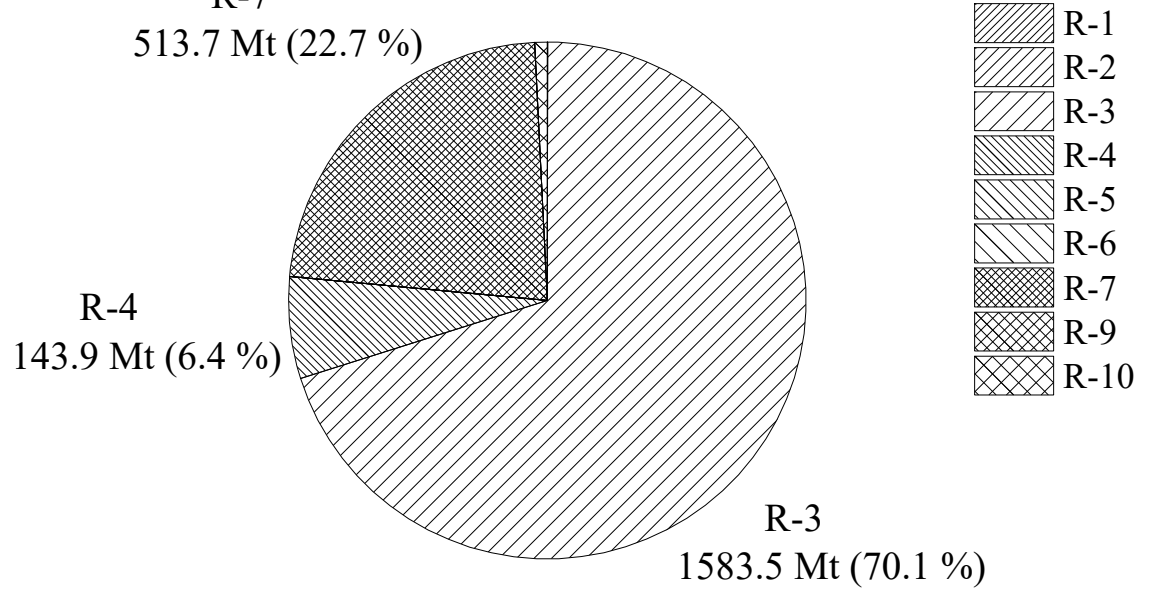

Figure 5. The amount of recycled slag, by R-type, in the Republic of Korea (2019).

Figure 6 shows the changes in usage of recycled for blast furnace and steelmaking slag over 10 years in the ROK. The usage categories are categorized into cement, road, banking, civil construction, brick/concrete, fertilizer, process reuse, and others. The blast furnace slag recycled as raw materials for cement showed the greatest change in usage, increasing from $60 \%$ in 2010 to $80 \%$ in 2019 (Figure 6a). From 2010, the amount of blast furnace slag that was used for road construction (21\%) and banking material (18\%), gradually decreased and was instead used recycled as raw materials for cement. This reflects the global trend to resolve environmental disputes and eliminate pollution by safely recycling slag, through a kiln process $\left(1450{ }^{\circ} \mathrm{C}\right)$, as cement raw materials rather than through direct recycling. Figure $6 \mathrm{~b}$ shows that steelmaking slag was recycled in all seven categories. The proportion recycled as road, banking, and process reuse varied from $1.9 \%$ to $22.5 \%, 26.5 \%$ to $46.3 \%$, and $11.9 \%$ to $20.5 \%$, respectively. 
(a)

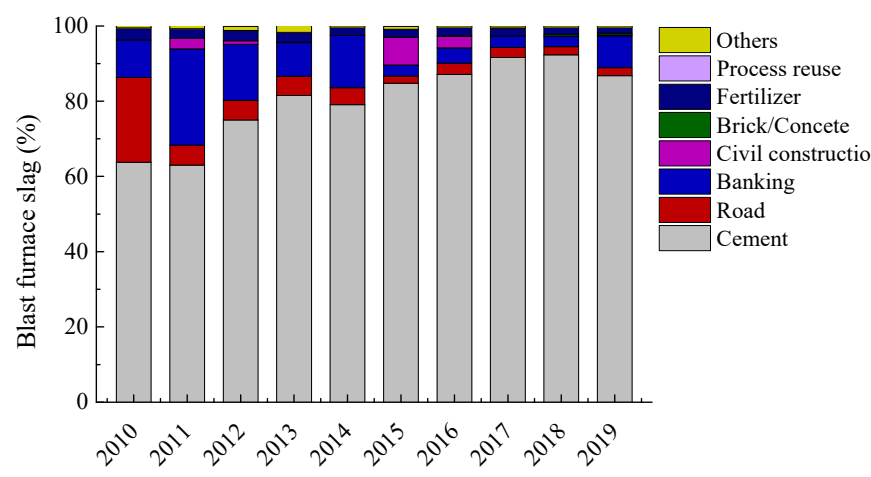

(b)

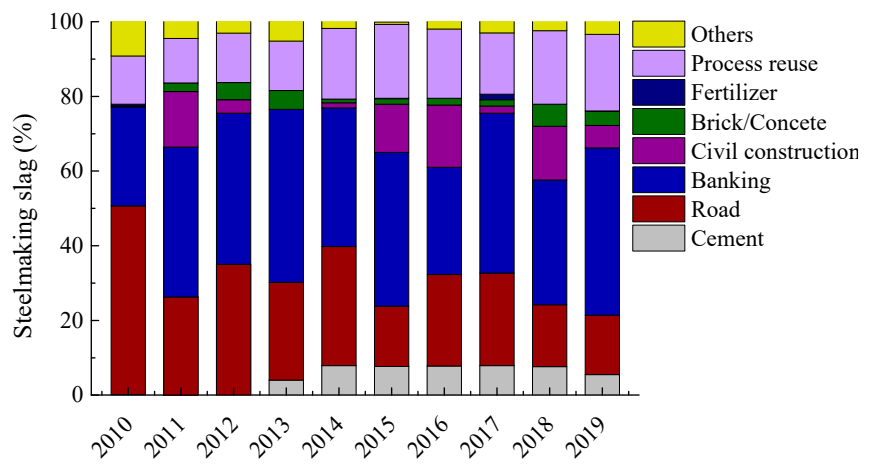

Figure 6. Changes in usage of (a) blast furnace slag and (b) steelmaking slag in the Republic of Korea between 2010 and 2019.

Table 2 summarizes the applications of recycled slag in different countries. In Japan, Europe, the United States, and China, slag is used in road construction, cement products, internal recycling, construction, and agriculture (Figure S4). The Japan Steel Association produced 137,000 tons in 2017 , with a reuse rate of $100 \%$ [21]. Of this, $35 \%$ was reused for road construction and $32 \%$ for construction, with applications categorized into cement raw materials, soil improvement, internal and external recycling, and other uses. In Japan, steel slag is used to reduce $\mathrm{H}_{2} \mathrm{~S}$ in the sea; thus, effective use of steel slag can also improve the marine environment. According to a survey by the European Steel Association, 28 countries in Europe together generated 478,000 tons of steel slag in 2018 [22]. Based on 2018 data from the European Steel Association, 69.9\% of this slag was recycled for road construction, $13.4 \%$ for metallurgical use, $5.5 \%$ for cement and concrete, and $5.3 \%$ for other uses [22]. According to a United States Geological Survey report, the United States produced 170,000 tons of steel slag in 2019; cement production $(49.7 \%)$ was the largest application, while road construction, final disposal, and other uses each accounted for $15 \%$ [23]. Steel slag production in China reached $100 \mathrm{Mt}$ in 2013. As the reuse rate of steel slag in China is very low, an accumulated $3 \mathrm{Mt}$ of steel slag has been discarded; as such, the proportion of steel slag being used for roads or agriculture is small.

Table 2. The application of slag in different countries.

\begin{tabular}{|c|c|c|c|c|c|c|c|c|}
\hline Area & Usage & Republic of Korea & Japan & USA & EU & Australia & China & Remark \\
\hline Raw material & $\begin{array}{l}\text { Cement raw material } \\
\text { Concrete admixture } \\
\text { Silicate fertilizer }\end{array}$ & $\begin{array}{l}\bigcirc \\
\bigcirc \\
\bigcirc\end{array}$ & $\begin{array}{l}\bigcirc \\
\bigcirc \\
\bigcirc\end{array}$ & $\begin{array}{l}0 \\
\bigcirc \\
0\end{array}$ & $\begin{array}{l}\bigcirc \\
\bigcirc \\
\bigcirc\end{array}$ & $\begin{array}{l}0 \\
0 \\
0\end{array}$ & $\begin{array}{l}0 \\
0 \\
-\end{array}$ & \\
\hline Aggregate & $\begin{array}{c}\text { Brick clay } \\
\text { Concrete aggregate } \\
\text { Banking } \\
\text { Soil covering } \\
\text { Dike construction } \\
\text { Public water surface backfilling } \\
\text { Road aggregate } \\
\text { Chemical construction } \\
\text { Dewatering aggregate } \\
\text { Non-skid aggregate } \\
\text { Retaining wall and backfilling } \\
\text { Rubble stone }\end{array}$ & $\begin{array}{l}0 \\
0 \\
0 \\
0 \\
0 \\
0 \\
0 \\
0 \\
0 \\
0 \\
0 \\
0\end{array}$ & $\begin{array}{l}- \\
\\
0 \\
- \\
- \\
0 \\
0 \\
- \\
0 \\
- \\
-\end{array}$ & $\begin{array}{l}0 \\
0 \\
0 \\
0 \\
- \\
0 \\
0 \\
- \\
- \\
0 \\
0 \\
0\end{array}$ & $\begin{array}{l}- \\
0 \\
- \\
- \\
0 \\
- \\
0 \\
- \\
0 \\
- \\
0 \\
-\end{array}$ & $\begin{array}{l}0 \\
0 \\
0 \\
0 \\
- \\
0 \\
0 \\
- \\
0 \\
0 \\
0 \\
0\end{array}$ & $\begin{array}{l}0 \\
0 \\
0 \\
0 \\
- \\
0 \\
0 \\
- \\
- \\
- \\
0 \\
0\end{array}$ & Road construction \\
\hline Other & $\begin{array}{c}\text { Rockwool } \\
\text { Pigment } \\
\text { Soil amendment } \\
\text { Chemical additive } \\
\text { Processing material } \\
\text { Railway material } \\
\text { Wastewater treatment } \\
\text { Filter } \\
\text { Land fill material } \\
\text { Mining wastewater treatment } \\
\text { Building roof materials }\end{array}$ & $\begin{array}{l}0 \\
0 \\
0 \\
0 \\
0 \\
- \\
- \\
- \\
- \\
- \\
-\end{array}$ & $\begin{array}{l}- \\
0 \\
0 \\
- \\
0 \\
0 \\
- \\
- \\
- \\
-\end{array}$ & $\begin{array}{l}0 \\
- \\
0 \\
0 \\
- \\
0 \\
0 \\
0 \\
0 \\
0 \\
0\end{array}$ & $\begin{array}{l}0 \\
- \\
0 \\
- \\
- \\
0 \\
0\end{array}$ & $\begin{array}{l}0 \\
- \\
- \\
- \\
- \\
- \\
- \\
0 \\
- \\
- \\
-\end{array}$ & $\begin{array}{l}- \\
- \\
- \\
- \\
- \\
0 \\
- \\
- \\
- \\
-\end{array}$ & $\begin{array}{c}\text { Magnetic separation } \\
\text { Remove nitrous and } \\
\text { phosphorus } \\
\text { Trout farm }\end{array}$ \\
\hline
\end{tabular}




\subsection{Steel Slag Management Regulations and Legal Position in the Republic of Korea}

Table 3 shows the regulations and guidelines for the aging period of slag in different countries. The ROK determines the required aging period of slag by size. Slag with a particle size less than $100 \mathrm{~mm}$ must undergo a natural aging period of at least 1 month, while slag greater than $100 \mathrm{~mm}$ in size must undergo a natural aging period of at least 3 months. The aging period and method are not determined by its slag type.

Table 3. Regulations for the recycling of slag in different countries.

\begin{tabular}{|c|c|c|}
\hline Country & Slag Type & Regulation and Guideline About Slag Aging \\
\hline Republic of Korea & Steel slag & $\begin{array}{l}\text { - Size } \leqq 100 \mathrm{~mm} \text {, stockpiled for at least } 1 \text { month } \\
\text { - Size } \geqq 100 \mathrm{~mm} \text {, stockpiled for at least } 3 \text { months }\end{array}$ \\
\hline \multirow[b]{2}{*}{$\begin{array}{l}\text { USA } \\
(\mathrm{DOT})\end{array}$} & $\begin{array}{l}\text { Air-cooled slag or } \\
\text { blast furnace slag }\end{array}$ & $\begin{array}{c}\text { - Stockpiled for a minimum of } 1 \text { month } \\
\text { - Must pass the test of leachate determination } \\
\text { (bucket test) }\end{array}$ \\
\hline & Steelmaking slag & $\begin{array}{l}\text { - Stockpiled for } 6 \text { months to allow hydration and } \\
\text { expansion } \\
\text { - ASTM D4792 [00(2006) Standard Test Method } \\
\text { for Potential Expansion of Aggregates from } \\
\text { Hydration Reactions] }\end{array}$ \\
\hline Belgium & Steelmaking slag & $\begin{array}{l}\text { - Stockpiled for a minimum of } 12 \text { months } \\
\text { - Free CaO: } \leqq 4.5 \%\end{array}$ \\
\hline Netherlands & Steelmaking slag & $\begin{array}{l}\text { - Stockpiled for a minimum of } 12 \text { months } \\
\text { - Free CaO: } \leqq 4.5 \%\end{array}$ \\
\hline Australia & Steelmaking slag & - Stockpiled for 1 3 months \\
\hline New Zealand & Steelmaking slag & - Stockpiled for 1 3 months \\
\hline Brazil & Steelmaking slag & - Stockpiled for a minimum of 6 months \\
\hline
\end{tabular}

In the United States, aging period guidelines are different for blast furnace slag and steelmaking slag. Blast furnace slag must be stockpiled for at least one month and must also pass a leaching test. Steelmaking slag must be stockpiled for six months, with consideration given to hydration and expansion, and must pass the "Standard Test Method for Potential Expansion of Aggregates from Hydration Reactions," an American Society for Testing and Materials (ASTM) D4792 test method.

In Belgium and the Netherlands, steelmaking slag must be stockpiled for at least 12 months; in particular, the free $\mathrm{CaO}$ content must be $4.5 \%$ or less, a requirement different from other countries. This is to alleviate concerns of hydration expansion in steelmaking slag. Australia and New Zealand require steelmaking slag to be stockpiled for one to three months for aging, while Brazil requires it to be stockpiled for at least six months.

Based on the steel slag aging regulations or guidelines of other countries, the slag aging period in the ROK should be extended, to a more long-term period. Furthermore, alternative indicators should be used, such as $\mathrm{pH}$ and the amount of free $\mathrm{CaO}$, to ensure ideal aging of steel slag.

Table 4 shows the legal position of slag in different countries. In the ROK, slag is managed as general waste and designated as a by-product in the Wastes Control Act. In Japan, slag is not considered as waste if used as a beneficial substance, as stipulated in the Law of Waste and Clean in the Waste Management Act and the Law for Promotion of Effective Utilization of Resources. In the United States, the federal government designates slag as a co-product, Pennsylvania designates it as a by-product rather than waste, Michigan defines only non-ferrous metal slag, generated during the smelting or melting processes of steel, as slag, and Ohio states that blast furnace slag generally does not cause environmental damage when reused for construction. Additionally, in Indiana and Illinois, steel slag is not subject to sanctions under the Wastes Control Act. The United Kingdom, the European Union, and Australia consider slag a by-product rather than waste. 
Table 4. The legal position of slag in different countries.

\begin{tabular}{|c|c|c|}
\hline Country & Main Content & Remark \\
\hline Republic of Korea & $\begin{array}{c}\text { Slag is classified as a "by-product" in the Resource Conservation } \\
\text { and Recycling Promotion Act }\end{array}$ & $\begin{array}{l}\text { Article } 3 \text { under Waste Management } \\
\text { Act in Republic of Korea }\end{array}$ \\
\hline Japan & $\begin{array}{c}\text { - Law promoting effective use of resources: slag material is a } \\
\text { co-product of the steel industry and is defined as a special resource } \\
\text { - Act on the Promotion of Effective Utilization of Resources: slag is } \\
\text { not waste if used as a beneficial material }\end{array}$ & \\
\hline \multirow{5}{*}{ US } & $\begin{array}{l}\text { Slag is a co-product rather than a by-product or waste, according to } \\
\text { federal government and in certain states }\end{array}$ & United States \\
\hline & $\begin{array}{l}\text { Department of Environmental Protection (DEP): slag is a } \\
\text { co-product rather than a by-product or waste }\end{array}$ & Pennsylvania state \\
\hline & $\begin{array}{l}\text { Compo Laws } \S 324.11506(\mathrm{I})(\mathrm{f}) \text {. "Slag" is defined as "the } \\
\text { nonmetallic product resulting from melting or smelting operations } \\
\text { for iron or steel" }\end{array}$ & Michigan state \\
\hline & $\begin{array}{l}\text { The policy also notes that blast furnace slag generally does not have } \\
\text { negative environmental effects when used as a construction } \\
\text { material }\end{array}$ & Ohio state \\
\hline & $\begin{array}{l}\text { Steelmaking slag is not covered by solid waste regulations in } \\
\text { Indiana or other states }\end{array}$ & Indiana, Illinois state \\
\hline UK & $\begin{array}{l}\text { Blast furnace slag defined as a by-product. } \\
\text { BFS produced in the UK could be classified as a by-product }\end{array}$ & $\begin{array}{l}\text { www.environment-agency.gov.uk } \\
\text { (accessed on 6 July 2021) }\end{array}$ \\
\hline EU & $\begin{array}{c}\text { - Granulated slag from the production of iron and steel is } \\
\text { considered to be a product in Austria and in many Organizations } \\
\text { for Economic Co-operation and Development member countries } \\
\text { - In Europe, steel slag and blast furnace slag products have been } \\
\text { eliminated from the European Waste Catalogue } \\
\text { - Slag treated with granulation, palletization, foaming, separation, } \\
\text { crushing, sieving, and milling are excluded }\end{array}$ & $\begin{array}{l}\text { European works council } 100201 \\
\text { waste the processing of slag } \\
100202 \text { unprocessed slag }\end{array}$ \\
\hline Australia & Slag is a by-product of the iron and steel manufacturing process & \\
\hline
\end{tabular}

\subsection{Environmental Risk Assessment of Steelmaking Slag in the Republic of Korea}

\subsubsection{General Physico-Chemical Estimation of Steelmaking Slag}

The $\mathrm{pH}$ of steel making slag for ROK ranged between 9.3 and 12.4, due to the high enough composition of free $\mathrm{CaO}$ which reacts with $\mathrm{H}_{2} \mathrm{O}$ to generate hydroxide ion $\left(\mathrm{HO}^{-}\right)$[24]. The composition of steel making slag $(n=16)$ was analyzed using XRF. Table 5 shows the result of comparative composition of steelmaking slag. The $\mathrm{CaO}(46.1 \%)$ and $\mathrm{SiO}_{2}(41.8 \%)$ were the main chemical composition of steelmaking slag in the ROK. Compared with other countries, $\mathrm{CaO}$ in the $\mathrm{ROK}$ was a main composition of steelmaking slag, which was higher than $35 \%$. Although total iron $\left(\mathrm{Fe}_{\mathrm{t}}\right)$ was not detected in ROK, the content of $\mathrm{Fe}_{\mathrm{t}}$ ranged between 17.4 and $24.36 \%$ in other countries. A previous study reported that $\mathrm{CaO}, \mathrm{MnO}$, and $\mathrm{MgO}$, which generate a considerable portion of steelmaking slag, can be used as alternatives for limestone, dolomite, and manganese ore to effectively reduce iron content and costs [25].

Figure 7 shows the contents of steelmaking slag for 18 samples in ROK. The standard of EAoR for media-contact recycling in ROK has been regulated for heavy metal such as $\mathrm{Cd}, \mathrm{Cu}, \mathrm{As}, \mathrm{Pb}, \mathrm{Zn}$, and $\mathrm{Ni}$. The results showed that heavy metals such as $\mathrm{Cd}(22 \%, n=32)$, $\mathrm{Cu}(28 \%, n=32)$, As $(28 \%, n=32), \mathrm{Pb}(1 \%, n=32)$, and $\mathrm{Zn}(22 \%, n=32)$ exceeded the Standards for soil environmental pollution. In the unregulated heavy metals of KS, the concentration of the heavy metals range was $\mathrm{Cr}(58.1-1032 \mathrm{mg} / \mathrm{kg}$; Avg. $1345 \mathrm{mg} / \mathrm{kg}), \mathrm{Ba}$ (25.7-16,103; Avg. 17.2 mg/kg), Pb (2.2-1578 mg/kg; Avg. 192 mg/kg), Zn (2-123 mg/kg; Avg. $22 \mathrm{mg} / \mathrm{kg}), \mathrm{V}(2-1000 \mathrm{mg} / \mathrm{kg}$; Avg. $388 \mathrm{mg} / \mathrm{kg})$, and Mo $(0.1-20,062 \mathrm{mg} / \mathrm{kg}$; Avg. $1509 \mathrm{mg} / \mathrm{kg}$ ). Previous studies reported that the content concentration of heavy 
metal investigated was Cd (0.1-128 mg/kg; Avg. $128 \mathrm{mg} / \mathrm{kg}), \mathrm{Cu}(3-540 \mathrm{mg} / \mathrm{kg}$; Avg. 540 mg/kg), As (0.15-244 mg/kg; Avg. 244 mg/kg), Pb (2-1040 mg/kg; Avg. 126 mg/kg), Zn (1-11,000 mg/kg; Avg. 11,000 mg/kg), Cr (4-32,700 mg/kg; Avg. 4798 mg/kg), Ba (24-1800 mg/kg; Avg. $366 \mathrm{mg} / \mathrm{kg}$ ) [26]. The concentration of $\mathrm{Zn}$ and $\mathrm{Pb}$ in ROK was 8-9 times and 1.5-2 times higher than that other countries; conversely, the concentration of heavy metals $(\mathrm{Cr}, \mathrm{Cd}, \mathrm{Ba}, \mathrm{Pb}$, and $\mathrm{Cu}$ ) was lower. Previous studies reported that $\mathrm{V}$ in steelmaking slag had a concentration of $690 \mathrm{mg} / \mathrm{kg}[5,27]$, and was hazardous with potential toxicity [28]. The steelmaking slag contains higher concentration of heavy metals than that of the soil as shown in this section. Heavy metals may have a negative effect on humans and the environment due to the characteristic of elution when recycled as media-contact recycling. Therefore, the leaching test proposed two ways, such as distilled water and seawater, when it comes to media-contact recycling.

Table 5. Chemical compositions of slag in different countries.

\begin{tabular}{|c|c|c|c|c|c|c|c|c|c|}
\hline \multirow{2}{*}{ Component } & \multicolumn{9}{|c|}{ Composition (\%) } \\
\hline & Republic of Korea & USA & Australia & Turkey & Japan & Brazil & Sweden & France & China \\
\hline $\mathrm{CaO}$ & 46.1 & $40-52$ & 35 & 38.62 & 45.8 & 45.2 & 45.0 & 47.71 & 42.92 \\
\hline $\mathrm{SiO}_{2}$ & 41.8 & 2.1 & 14 & 19.28 & 11.10 & 12.2 & 11.1 & 13.25 & 11.51 \\
\hline $\mathrm{Al}_{2} \mathrm{O}_{3}$ & - & $1-3$ & 5.5 & 2.71 & 1.9 & 0.8 & 1.9 & 3.04 & 1.4 \\
\hline $\mathrm{MgO}$ & 6.3 & $5-10$ & 7.7 & 8.05 & 6.5 & 5.5 & 9.6 & 6.37 & 4.36 \\
\hline $\mathrm{MnO}$ & 5.4 & $5-8$ & 5.7 & 7.52 & 5.3 & 7.1 & 3.1 & 2.64 & 4.04 \\
\hline $\mathrm{P}_{2} \mathrm{O}_{5}$ & - & $0.5-1$ & - & - & 1.7 & - & 0.23 & 1.47 & 0.83 \\
\hline $\begin{array}{c}\text { Total iron } \\
\left(\mathrm{Fe}_{\mathrm{t}}\right)\end{array}$ & - & - & - & 22.61 & 17.4 & 18.8 & 23.9 & 24.36 & 23.74 \\
\hline $\mathrm{s}$ & 0.08 & - & 0.1 & 0.28 & 0.06 & 0.07 & - & - & 0.07 \\
\hline $\mathrm{K}_{2} \mathrm{O}$ & - & - & 0.1 & - & - & - & - & - & - \\
\hline $\mathrm{Cr}_{2} \mathrm{O}_{3}$ & - & - & 1 & - & - & - & - & - & - \\
\hline $\mathrm{V}_{2} \mathrm{O}_{5}$ & - & - & 0.3 & - & - & - & - & - & - \\
\hline $\mathrm{Fe}_{2} \mathrm{O}_{3}$ & - & $10-40$ & 29 & - & - & - & - & - & - \\
\hline
\end{tabular}

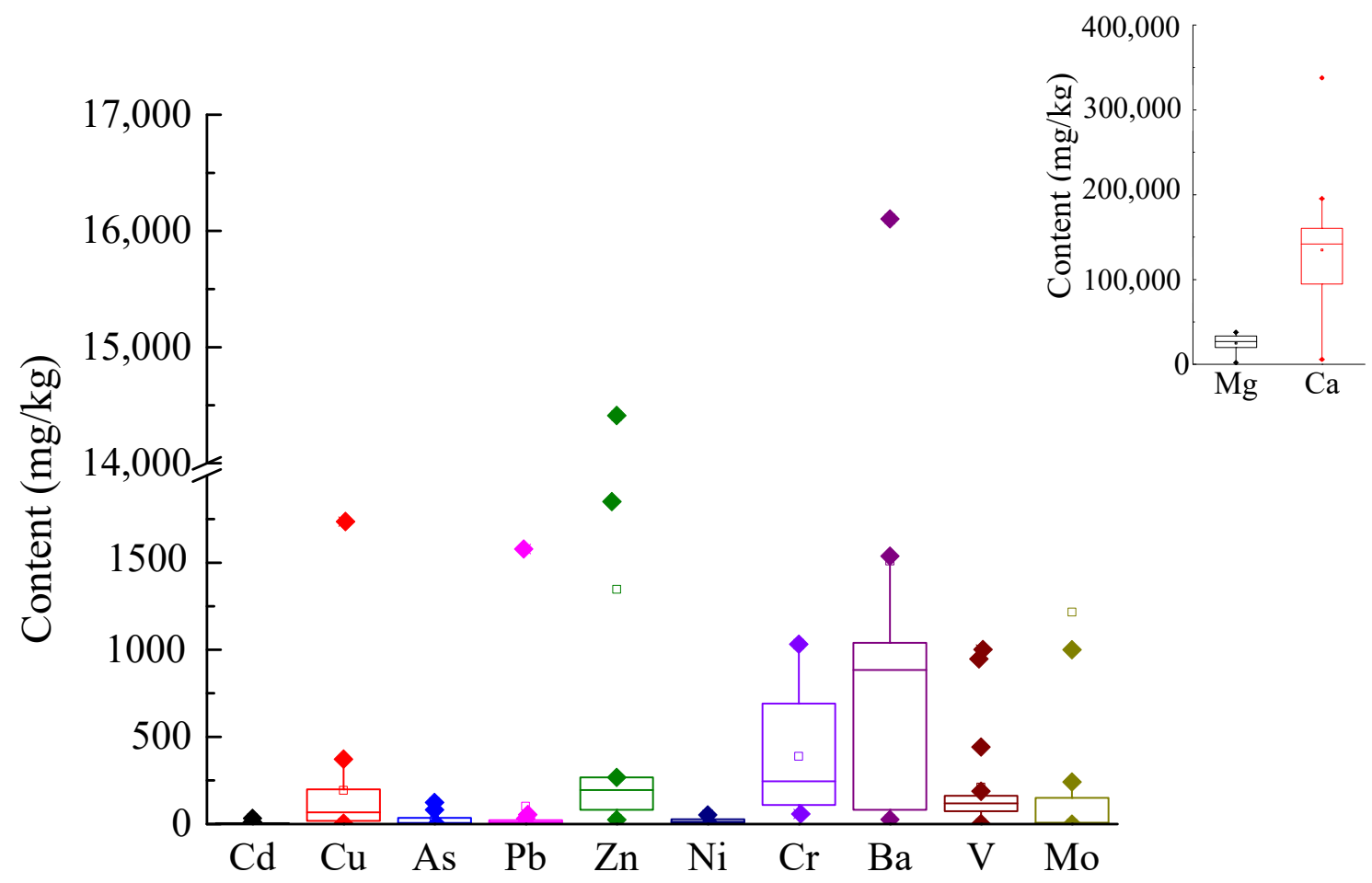

Figure 7. Heavy metal content in steelmaking slag. 


\subsubsection{Estimation of Leaching Test for Steelmaking Slag}

The leaching test was performed following with Waste Control Act. The results of leaching test are shown in Figure 8. Within 6 h, some heavy metals such as $\mathrm{Cu}, \mathrm{Zn}, \mathrm{Cr}, \mathrm{Ba}, \mathrm{V}$, and Mo were liquated under the leaching test using distilled water and seawater. Especially, $\mathrm{Zn}, \mathrm{Ba}$, and Mo showed an extensive range of 0.25-1.2, 0.4-2.07, and 0.1-31.8 mg/L, respectively. The high concentration of Mo released from steelmaking slag was not ignored although their concentration was detected one time. The leaching characteristic of heavy metals was observed according to different leachants such as distilled water and seawater. This suggests that the transport and transformation of hazardous heavy metals is possible based on their coordination environment, molecular geometry, and oxidation state when the steelmaking slag was reused or landfilled. In addition, the different leachability of heavy metals was shown according to the different eluent.

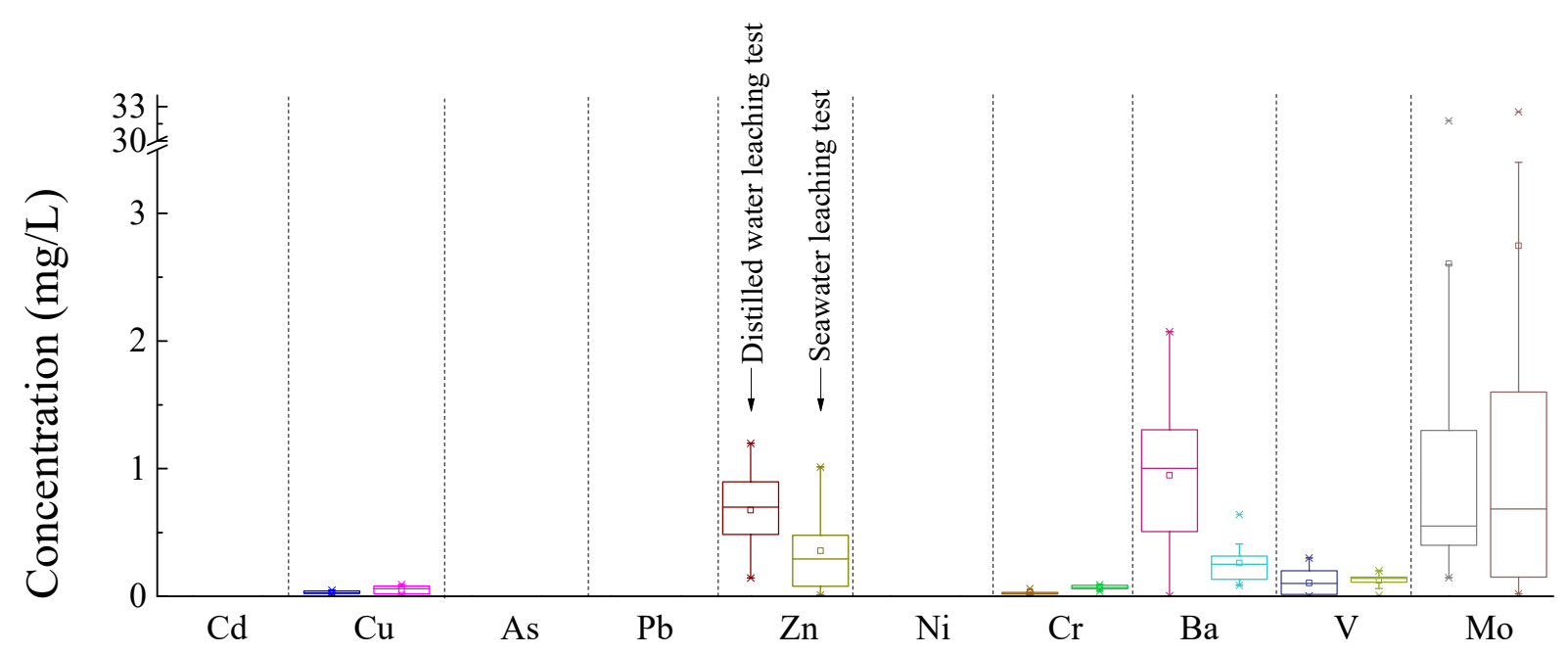

Figure 8. Concentrations of heavy metals based on the distilled water and seawater leaching tests.

Spanka M. [29] reported that $\mathrm{V}$ and Mo are hazardous heavy metals that are easy to leachate to alkali conditions, and have been shown to cause environmental and ecosystem damage [30]. Chaurand et al. [31] demonstrated that the toxicity of $\mathrm{Cr}$ and $\mathrm{V}$ was significantly different according to the oxidation state. The model of heavy metal transport model can estimate the environmental impact of heavy metals [30].

The concentration of Ca and Mg ranged between 1.442-398 and $0.049-0.8 \mathrm{mg} / \mathrm{L}$, respectively. These heavy metals also have a negative effect on the environment and humans. Mayes et al. [32] reported that $\mathrm{Mg}$ and $\mathrm{Ca}$ can increase hazardous sediment, which highlights the long-term damaging effect due to the storage and leaching of slags. Gomes et al. [33] suggested caution when reusing the steelmaking slag according to their monitoring data. The authors investigated the heavy metals of surface and ground water near steel companies and found high levels of V (1.65-1.8 $\mu \mathrm{g} / \mathrm{L})$ and Mo $(2.8-23.4 \mu \mathrm{g} / \mathrm{L})$, which contributed to environmental damage. Hull et al. [34] proposed V as potentially toxic under alkaline conditions, as previously shown [31,35], keeping mobility under neutral and alkaline $\mathrm{pH}$ conditions [36]. Seawater releases more heavy metals than distilled water, which can be explained as follows: (i) the $\mathrm{pH}$ of leachant in distilled water is more alkaline ( $\mathrm{pH}$ 9.3-12.5) than that of seawater ( $\mathrm{pH}$ 7.5-11.9). A previous study reported high heavy metal leachability when salt concentration is increased [37]. (ii) Substances travel with different speeds based on the different solutes such as salts, metals, and organics, which influences heavy metal release [38]. (iii) Effect of time frame affect to extrapolate between scales and conditions of percolation and leaching behavior [39,40]. (iv) Background matrices such as DOM, chloride, and sulfate impact the leaching behavior [41]. The concentrations of the heavy metals leached from steelmaking slag were generally much lower than the total concentrations, which was a solid $\mathrm{pH}$ dependency. 


\subsubsection{Evaluation of Toxicity with Aliivibrio fischeri}

The leaching solution obtained from the leaching test of steelmaking slag was used to estimate the potential toxicity using luminescent bacteria when the distilled water and seawater were used as the leachants (Figure 9). The inhibition value of toxicity using distilled water ranged between 0.8 and 1.0, meanwhile, the inhibition value of toxicity using seawater ranged between 0 and 0.4. $\mathrm{pH}$ and heavy metals might have contributed to these differences. The $\mathrm{pH}$ for leaching solution using distilled water and seawater was 9.1-12.0 and 7.4-11.2, respectively. Toxicity was increased with increasing $\mathrm{pH}$. In addition, the leaching of heavy metals was observed in high alkaline conditions [32], which increased toxicity. A previous study reported an increase in $\mathrm{Cr}$ and $\mathrm{V}$ toxicity while in oxidation state [31]. pH not only influences toxicity but also releases leachability of heavy metals. Fang et al. [42] reported that the hazardous wastes reused in soil or landfill can change the characterization of soil, thus prompting heavy metal leachability. Moreover, this toxicity may be influenced by other unknown substances generated during leaching test such as dissolved organic, inorganic, and transformation substances, and dissolved organic carbon-based ion different leachants.

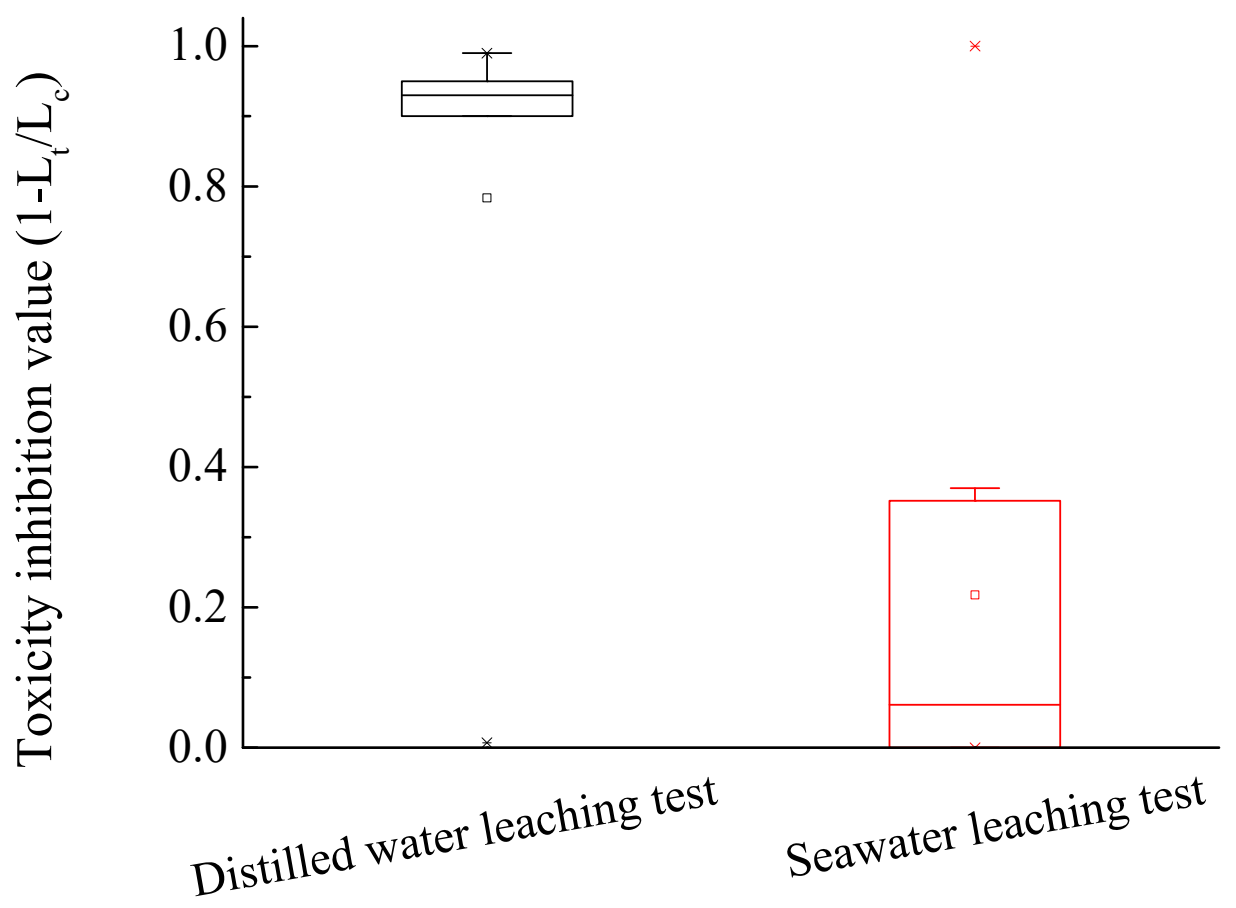

Figure 9. Toxicity of leaching test on Aliivibrio fischeri luminescent bacteria.

\subsection{Future of Steelmaking Slag Recycling}

New applications for recycling slag in the Republic of Korea were examined, based on those investigated in different countries (Table 6). The following new recycling applications were identified as feasible: iron recovery, railroad ballast aggregate, wastewater treatment filtering, building roof materials, marine forests, artificial reefs, tetrapod blocks, in situ capping, soil (ground) conditioning, and materials for red tide prevention (Table 6). Of these new applications, iron recovery was excluded from review because redox slag is not separated and discharged from blast furnace slag, while marine forests, artificial reefs, and tetrapod blocks were excluded from review as they are already designated for recycling by the Ministry of Food, Agriculture, Forestry and Fisheries. 
Table 6. New feasible usage for slag recycling.

\begin{tabular}{|c|c|c|}
\hline \multicolumn{2}{|r|}{ Usage } & Remark \\
\hline \multicolumn{2}{|c|}{$\begin{array}{c}\text { Raw materials } \\
\text { (cement, admixture, fertilizer, rockwool, ceramic) }\end{array}$} & \\
\hline \multicolumn{2}{|c|}{$\begin{array}{c}\text { Aggregate } \\
\text { (brick, concrete, road, ascon, rubble) }\end{array}$} & Use is specified in current recycling guidelines \\
\hline \multicolumn{2}{|c|}{ Filling caissons } & \\
\hline \multicolumn{3}{|c|}{ Anti-slip aggregate } \\
\hline \multicolumn{2}{|c|}{ Iron recovery } & Not yet possible (lack of technology) \\
\hline \multicolumn{2}{|c|}{ Railroad ballast } & $\begin{array}{l}\text { Excluded from review (sold according to road aggregate } \\
\text { standards) }\end{array}$ \\
\hline \multicolumn{2}{|c|}{ Building roof materials } & Excluded from review (ceramic material) \\
\hline \multirow[t]{2}{*}{ Water treatment } & Wastewater treatment, filter & $\begin{array}{c}\text { Excluded from review (patent application from a specific } \\
\text { company, involving atomizing a fine powder) } \\
\text { Sold as a product }\end{array}$ \\
\hline & Mine wastewater & Excluded from review \\
\hline \multirow{4}{*}{ Ocean } & Artificial reef & \multirow{2}{*}{$\begin{array}{c}\text { Excluded from review } \\
\text { Designated by other law (Ministry of Food, Agriculture, } \\
\text { Forestry and Fisheries) }\end{array}$} \\
\hline & Tetrapod block & \\
\hline & In situ capping & Reviewing \\
\hline & Materials for red tide prevention & Reviewing \\
\hline \multicolumn{2}{|c|}{ Soil conditioner } & Reviewing \\
\hline \multicolumn{2}{|c|}{ Fine aggregate substituted for sand in sewage pipe installation } & Reviewing \\
\hline
\end{tabular}

The applications that require close review are in situ capping, red tide prevention, and soil (ground) conditioning. For in situ capping (which involves the installation of a nonpolluted layer on top of a polluted sediment layer), the use of steelmaking slag reduces the quantity of material required to form a cap thickness of $100 \mathrm{~mm}$ or less, while also reducing facility costs by at least half (compared to other materials). Moreover, suitable particle sizes can be selected for each application environment during the production process, thereby facilitating quality control and expanding the applicability of steelmaking slag, relative to general sand. In situ capping with steelmaking slag has four main advantages. First, steelmaking slag has an excellent adsorption and removal capacity for phosphate, hydrogen sulfide, and heavy metals. Second, in actual experiments applying it in sea areas, in situ capping had an excellent inhibiting effect on leaching of pollutants from contaminated seabed sediments. Third, studies have reported inhibiting effects on leaching $(50 \%)$, adsorption $(40 \%)$, and chemical reactions $(10 \%)$. Fourth, in situ capping has been applied in the United States (rivers, lakes, ports, etc.), Japan, and Europe.

Using slag as a material for red tide prevention has the following advantages over using loess: first, the particle size is easily adjusted (during production). Second, there is reduced risk of pollution due to impurities (suspended solids) in the loess. Third, it can improve the habitat of Manila clams and blood clams inhabiting the surface layer of sediment. Fourth, it can improve the habitat of oysters and sea squirts farmed in the water layer. Fifth, it is easily sprayed over an area. The loess spraying method, which is commonly used for red tide prevention, involves dissolving and spraying natural loess in the seawater. This method is unscientific, has not been proven effective, and uses more loess than necessary, thus causing damage to nature and secondary marine pollution.

There are five reasons to use slag as a soil (ground) conditioner. First, it can be used to create a firm surface on ultra-soft ground comprising dredged soil or marine clay along the coast. Second, it can replace natural sand used in the sand compaction pile method, where it acts like crushed stone or gravel. Third, it is applicable in various methods, such as the 
preloading, replacement, and surface drainage methods. Fourth, it can be used as loading embankment and pavement material. Lastly, there are numerous documented cases where slag was applied as a ground conditioner $[15,16]$.

\section{Conclusions}

In the ROK, the recycling of steel slag has progressed steadily until 2016. Recycling methods for safer and more diverse recycling applications were analyzed from 2016, after the introduction of the EAoR system. Current data on steel slag recycling in the ROK were analyzed and compared with corresponding data from several other countries. We proposed a solution through the determination of the extensive applications for steelmaking slag, which is an indicator of the proportion of recycled resources used, and determined the factors that hamper recycling. The key findings of our study are as follows:

1. The ROK recycled as much as $98.3 \%$ of their generated slag, which is relatively high compared to other countries. However, the need to minimize environmental pollution while maintaining media-contact recycling was recognized. The ROK does not use much slag in road construction, agriculture, or offshore structures, compared to some advanced countries.

2. We identified a need for environmental recycling standards. Methods for improving the aging period of steelmaking slag must also be considered. The environmental effects of different aging periods must be determined, and further research on $\mathrm{CaO}$ content and indirect aging evaluation methods is needed.

3. In the EAoR system, which has been utilized in the ROK since 2016, products that are environmentally certified are exempt from EAoR regulations. Moreover, there is an urgent need for environmental standards relating to slag that is recycled as a product, and the recycling and environmental label certification for products should also be amended.

4. To effectively recycle steelmaking slag, an application plan is proposed, which involves in situ capping, materials for red tide prevention, soil conditioning, and fine aggregate substituted for sand in sewage pipe installation

Based on these results, sustainable resource management can reuse resources and effective recycling within a safe range for human health and the environment by extending the applications for steelmaking slag in the ROK. The suggested applications are promising, however, they should be monitored and periodically tested over a longer period.

Supplementary Materials: The following are available online at https: / www.mdpi.com/article / 10.3390/su13168805/s1, Figure S1: Schematic of percolation test, Figure S2: Procedure of toxicity test, Figure S3: Schematic of estimation toxicity using with Daphnia magna, Figure S4: Steel slag utilization in Japan, Europe, the United States, and China, Table S1: Standard guidelines for recycling of slag in different countries, Table S2: Comparison of leaching methods in different countries.

Author Contributions: Conceptualization, M.-Y.L. and T.-W.J.; methodology, J.-H.K.; software, J.-H.K.; validation, M.-Y.L., J.-H.K. and D.-G.H.; formal analysis, J.-H.K. and M.-Y.L.; investigation, J.-H.K. and M.-Y.L.; resources, J.-H.K.; data curation, M.-Y.L. and T.-W.J.; writing-original draft preparation, M.-Y.L.; writing-review and editing, Y.-S.Y. and M.-S.Y.; visualization, T.-W.J.; supervision, T.-W.J.; project administration, T.-W.J.; funding acquisition, T.-W.J. and M.-S.Y. All authors have read and agreed to the published version of the manuscript.

Funding: This research was funded by the National Institute of Environmental Research, Republic of Korea (No. NIER-2020-03-01-006).

Data Availability Statement: Not applicable.

Acknowledgments: The authors acknowledge the research support provided by the Ministry of Environment (MOE) of the Republic of Korea.

Conflicts of Interest: The authors declare no conflict of interest. 


\section{References}

1. World Steel Association. Steel Statistical Yearbook 2020. Available online: https:/ /www.worldsteel.org/steel-by-topic/statistics/ steel-statistical-yearbook.html (accessed on 5 January 2021).

2. Guo, J.; Bao, Y.; Wang, M. Steel slag in China: Treatment, recycling, and management. Waste Manag. 2018, 78, 318-330. [CrossRef]

3. Korea Iron \& Steel Association. Production and Uses of Steel Slag in the Republic of Korea. Available online: https://www.kosa. or.kr/statistics/.jsp (accessed on 9 February 2020).

4. Ministry of Land Infrastructure and Transport Republic of Korea. Production and Demand of Aggregate in the Republic of Korea. 2019. Available online: https:/ / www.index.go.kr/potal/main/EachDtlPageDetail.do?idx_cd=1223 (accessed on 19 July 2021).

5. Geiseler, J. Use of steelworks slag in Europe. Waste Manag. 1996, 16, 59-63. [CrossRef]

6. Topkaya, Y.; Sevinç, N.; Günaydın, A. Slag treatment at Kardemir integrated iron and steel works. Int. J. Miner. Process. 2004, 74, 31-39. [CrossRef]

7. Diao, J.; Zhou, W.; Ke, Z.; Qiao, Y.; Zhang, T.; Liu, X.; Xie, B. System assessment of recycling of steel slag in converter steelmaking. J. Clean. Prod. 2016, 125, 159-167. [CrossRef]

8. Ortiz, N.; Pires, M.A.F.; Bressiani, J.C. Use of steel converter slag as nickel adsorber to wastewater treatment. Waste Manag. 2001, 21, 631-635. [CrossRef]

9. Ponsot, I.; Bernardo, E. Self glazed glass ceramic foams from metallurgical slag and recycled glass. J. Clean. Prod. 2013, 59, 245-250. [CrossRef]

10. Sarfo, P.; Wyss, G.; Ma, G.; Das, A.; Young, C. Carbothermal reduction of copper smelter slag for recycling into pig iron and glass. Miner. Eng. 2017, 107, 8-19. [CrossRef]

11. Ferreira, V.J.; Sáez-De-Guinoa Vilaplana, A.; García-Armingol, T.; Aranda-Usón, A.; Lausín-González, C.; López-Sabirón, A.M.; Ferreira, G. Evaluation of the steel slag incorporation as coarse aggregate for road construction: Technical requirements and environmental impact assessment. J. Clean. Prod. 2016, 130, 175-186. [CrossRef]

12. Pasetto, M.; Baliello, A.; Giacomello, G.; Pasquini, E. Sustainable solutions for road pavements: A multi-scale characterization of warm mix asphalts containing steel slags. J. Clean. Prod. 2017, 166, 835-843. [CrossRef]

13. Pan, S.-Y.; Adhikari, R.; Chen, Y.-H.; Li, P.; Chiang, P.-C. Integrated and innovative steel slag utilization for iron reclamation, green material production and $\mathrm{CO}_{2}$ fixation via accelerated carbonation. J. Clean. Prod. 2016, 137, 617-631. [CrossRef]

14. Zhang, X.; Ma, G.; Tong, Z.; Xue, Z. Microwave-assisted selective leaching behavior of calcium from Basic Oxygen Furnace (BOF) slag with ammonium chloride solution. J. Min. Metall. Sect. B Metall. 2017, 53, 139-146. [CrossRef]

15. Fujisawa, N.; Fukushima, M.; Yamamoto, M.; Iwai, H.; Komai, T.; Kawabe, Y.; Liu, D. Structural alterations of humic acid fractions in a steel slag-compost fertilizer during fertilization. Analysis by pyrolysis/methylation-gas chromatography/mass spectrometry. J. Anal. Appl. Pyrolysis 2012, 95, 126-133. [CrossRef]

16. Gómez-Nubla, L.; Aramendia, J.; Fdez-Ortiz de Vallejuelo, S.; Carrero, J.A.; Madariaga, J.M. Focused ultrasound energy over steel slags as a fast tool to assess their environmental risk before and after their reuse in agriculture and civil constructions. Microchem. J. 2017, 132, 268-273. [CrossRef]

17. Drissen, P.; Ehrenberg, A.; Kühn, M.; Mudersbach, D. Recent Development in Slag Treatment and Dust Recycling. Process. Metall. 2009, 80, 737-745.

18. Nakase, K.; Matsui, A.; Kikuchi, N.; Miki, Y.; Kishimoto, Y.; Goto, I.; Nagasaka, T. Fundamental Research on a Rational Steelmaking Slag Recycling System by Phosphorus Separation and Collection. J. Manuf. Sci. Prod. 2013, 13, 39-45. [CrossRef]

19. Riley, A.L.; Mayes, W.M. Long-term evolution of highly alkaline steel slag drainage waters. Environ. Monit. Assess. 2015, 187, 463. [CrossRef]

20. Ministry of Enviornment Republic of Korea. Guidelines for Recycling Steel Slag and Coal Ash Discharging Business. 2009. Available online: https: / / www.law.go.kr/LSW/admRulLsInfoP.do?admRulSeq=2100000202184\#: \{\}:text=1.\%20\%EC\%B2\%A0

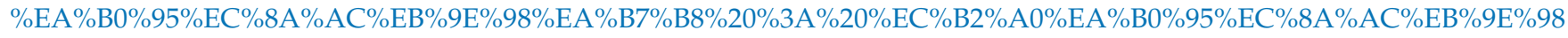

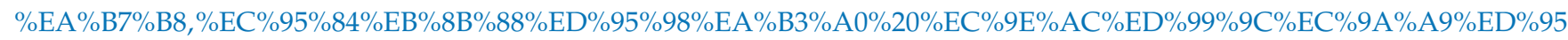
$\%$ A0\%20\%EC $\% 88 \% 98 \% 20 \% E C \% 9 E \% 88 \%$ EB\%8B \%A4 (accessed on 2 February 2021).

21. Nippon Slag Association. Production and Uses of Blast Furnace Slag in Japan. Available online: https://www.slg.jp/pdf/Blast\% 20Furnace\%20Slag\%202017FY\%20rev.pdf (accessed on 22 February 2021).

22. Euro Slag Association. Euroslag Statistics 2018. Available online: https://www.euroslag.com/products/statistics/statistics-2018/ (accessed on 5 June 2018).

23. United State Geological Survey. Iron and steel slag. Available online: https://prd-wret.s3-us-west-2.amazonaws.com/assets / palladium/production/atoms / files/mcs-2019-fesla.pdf (accessed on 19 February 2019).

24. Mayes, W.M.; Younger, P.L.; Aumônier, J. Hydrogeochemistry of Alkaline Steel Slag Leachates in the UK. Water Air Soil Pollut. 2008, 195, 35-50. [CrossRef]

25. Hou, D.; Li, D.; Xu, G.; Zhang, Y. Superposition model for analyzing the dynamic ground subsidence in mining area of thick loose layer. Int. J. Min. Sci. Technol. 2018, 28, 663-668. [CrossRef]

26. Piatak, N.M.; Parsons, M.B.; Seal, R.R. Characteristics and environmental aspects of slag: A review. Appl. Geochem. 2015, 57, 236-266. [CrossRef]

27. Motz, H.; Geiseler, J. Products of steel slags an opportunity to save natural resources. Waste Manag. 2001, 21, 285-293. [CrossRef] 
28. Proctor, D.M.; Shay, E.C.; Fehling, K.A.; Finley, B.L. Assessment of Human Health and Ecological Risks Posed by the Uses of Steel-Industry Slags in the Environment. Hum. Ecol. Risk Assess. Int. J. 2010, 8, 681-711. [CrossRef]

29. Spanka, M. Minimizing the release of Chromium, Molybdenum, Vanadium, and Fluoride from Steelwork Slags. 2018. Available online: https:/ / kups.ub.uni-koeln.de/8583/1/Spanka\%20\%282018\%29.pdf (accessed on 30 July 2021).

30. Fang, H.; Huang, L.; Wang, J.; He, G.; Reible, D. Environmental assessment of heavy metal transport and transformation in the Hangzhou Bay, China. J. Hazard Mater. 2016, 302, 447-457. [CrossRef] [PubMed]

31. Chaurand, P.; Rose, J.; Briois, V.; Olivi, L.; Hazemann, J.L.; Proux, O.; Domas, J.; Bottero, J.-Y. Environmental impacts of steel slag reused in road construction: A crystallographic and molecular (XANES) approach. J. Hazard Mater. 2007, 139, 537-542. [CrossRef]

32. Mayes, W.M.; Younger, P.L.; Aumonier, J. Buffering of Alkaline Steel Slag Leachate across a Natural Wetland. Environ. Sci. Technol. 2006, 40, 1237-1243. [CrossRef] [PubMed]

33. Gomes, H.I.; Mayes, W.M.; Baxter, H.A.; Jarvis, A.P.; Burke, I.T.; Stewart, D.I.; Rogerson, M. Options for managing alkaline steel slag leachate: A life cycle assessment. J. Clean. Prod. 2018, 202, 401-412. [CrossRef]

34. Hull, S.L.; Oty, U.V.; Mayes, W.M. Rapid recovery of benthic invertebrates downstream of hyperalkaline steel slag discharges. Hydrobiologia 2014, 736, 83-97. [CrossRef]

35. Burke, I.T.; Mayes, W.M.; Peacock, C.L.; Brown, A.P.; Jarvis, A.P.; Gruiz, K. Speciation of arsenic, chromium, and vanadium in red mud samples from the Ajka spill site, Hungary. Environ. Sci. Technol. 2012, 46, 3085-3092. [CrossRef]

36. Takeno, N. Atlas of Eh-pH Diagrams Intercomparison of Thermodynamic Databases Geological Survey of Japan Open File Report No.419. 2005. Available online: https://www.gsj.jp/researches/openfile/openfile2005/openfile0419.html (accessed on 22 July 2021).

37. Hernández, P.; Dorador, A.; Martínez, M.; Toro, N.; Castillo, J.; Ghorbani, Y. Use of Seawater/Brine and Caliche's Salts as Clean and Environmentally Friendly Sources of Chloride and Nitrate Ions for Chalcopyrite Concentrate Leaching. Minerals 2020, 10, 477. [CrossRef]

38. Susset, B.; Grathwohl, P. Leaching standards for mineral recycling materials-A harmonized regulatory concept for the upcoming German Recycling Decree. Waste Manag. 2011, 31, 201-214. [CrossRef]

39. Dijkstra, J.J.; Meeussen, J.C.L.; Comans, R.N.J. Leaching of Heavy Metals from Contaminated Soils: An Experimental and Modeling Study. Environ. Sci. Technol. 2004, 38, 4390-4395. [CrossRef]

40. Dijkstra, J.J.; van der Sloot, H.A.; Comans, R.N.J. The leaching of major and trace elements from MSWI bottom ash as a function of $\mathrm{pH}$ and time. Appl. Geochem. 2006, 21, 335-351. [CrossRef]

41. Grathwohl, P.; Susset, B. Comparison of percolation to batch and sequential leaching tests: Theory and data. Waste Manag. 2009, 29, 2681-2688. [CrossRef] [PubMed]

42. Fang, W.; Delapp, R.C.; Kosson, D.S.; van der Sloot, H.A.; Liu, J. Release of heavy metals during long-term land application of sewage sludge compost: Percolation leaching tests with repeated additions of compost. Chemosphere 2017, 169, 271-280. [CrossRef] [PubMed] 